\title{
Total protein output during rapid reduction of bile salt secretion rates in man
}

\author{
P ROBERT C HARVEY, JULIUS L TOTH, G ARAVINDA UPADHYA, \\ RAY G ILSON, AND STEVEN M STRASBERG \\ From the Department of Surgery and Research Institute, Mount Sinai Hospital, Toronto, Canada
}

\begin{abstract}
SUMmARY An investigation was undertaken to study the effect of bile salt secretion on total biliary protein secretion in man. Bile was collected in eight patients from a tube in the bile duct. Collection was started after a meal and continued for six hours, in order to obtain bile salt secretion rates over the entire physiological range. Total protein secretion rates did not vary with change in bile salt secretion or bile flow. The protein pattern assessed by SDS-PAGE did not vary with bile salt secretion. The results indicate that bile salt secretion has little influence on biliary protein secretion under these conditions in man. Changes in bile salt secretion were associated with linear change in bile flow, but there was no relationship between bile flow and protein secretion rates. This argues against convective sieving of plasma proteins into bile.
\end{abstract}

There are two sources of hepatic bile proteins, serum proteins which pass from blood to bile and proteins synthesised in the liver and exported into bile. ${ }^{1-5}$ Some serum derived bile proteins such as $\operatorname{IgA}$ are transported across the hepatocyte by specific vesicular systems ${ }^{67}$ and their bile concentration exceeds their blood concentration $;^{48}$ however, most serum derived proteins have a much lower concentration in bile than serum and seem to enter bile at a rate inversely proportional to their molecular weight. ${ }^{14}$

Little is known about factors determining the rate of protein secretion. Studies in animal models have found a relationship between bile salt secretion and secretion of membrane bound enzymes into bile. . $^{y-12}$ Studies on the influence of bile salt secretion on the secretion of other biliary proteins or total protein secretion are conflicting, however, with some investigators observing an effect ${ }^{12}$ while others have found that protein secretion is not related to biliary secretion of bile acids..$^{91013}$ In this study we have examined the effect on protein secretion of a rapid reduction in

Address for correspondence: P R C Harvey, $6(0)$ University Avenue, \#988, Toronto, Ontario M5G 1 X5, Canada.

Accepted for publication 22 July 1988 bile salt secretion produced by interruption of the enterohepatic circulation. We found that bile salts do not appear to influence protein secretion during rapid reduction of bile salt secretion induced by interruption of the enterohepatic circulation. A second observation is that protein secretion rates are not influenced by changes in bile flow. This does not support the concept ${ }^{4}$ that serum proteins enter bile by convective sieving through the paracellular pathway.

\section{Methods}

PATIENTS

Bile was obtained with informed consent from patients who had the bile duct explored during an operation for gall stone disease. As part of this procedure a $t$-tube is placed in the bile duct and one limb is exteriorised. Four days later the bile ducts were examined by cholangiography and shown to be free of residual stones. The exterior limb of the t-tube was then clamped until the study six days later to restore the normal passage of bile into the duodenum. The tube was removed immediately after the study. Eight patients (three men and five women) were studied. The mean age was $57 \cdot 1$ years $(20 \cdot 3)$ (SD) and mean weight $69 \cdot 1 \mathrm{~kg}(17 \cdot 0)(\mathrm{SD})$. 

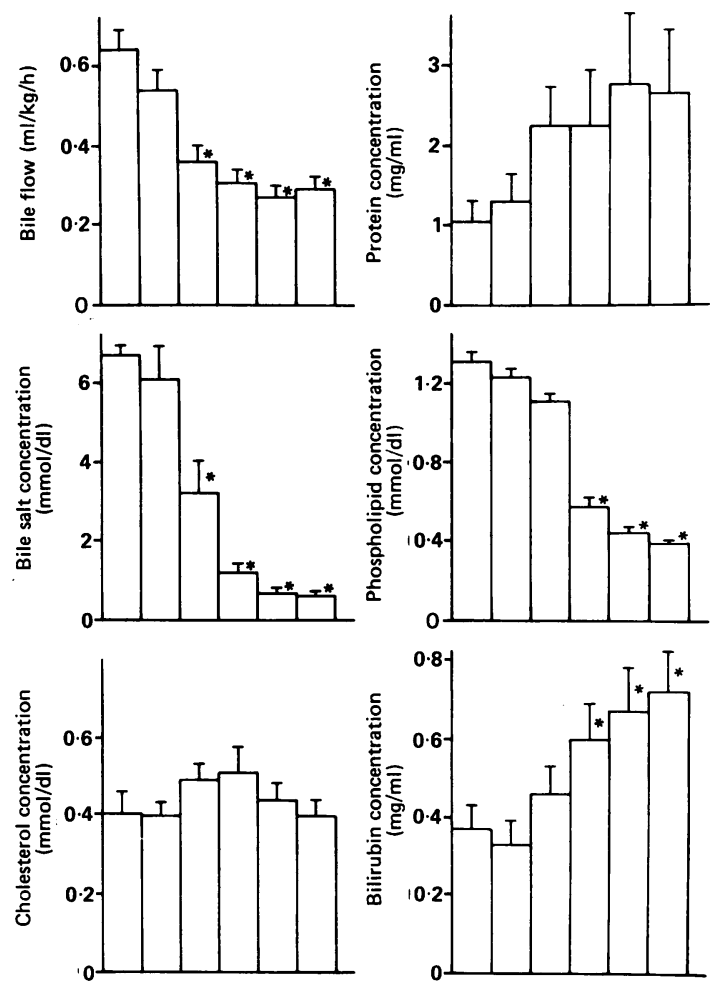

Fig. 1 Mean hourly bile flows and concentration of biliary lipids and proteins of hepatic bile collected from eight individual patients over a six hour period. Each bar represents results from bile collected over 60 minute intervals. * Significantly different from results of bile collected during first hour.

\section{STUDY PROTOCOL}

Patients were given a standard full diet breakfast at 0830 on the study day. Thirty minutes later the t-tube was opened: The first $3 \mathrm{ml}$ bile - that is, in the tubing, were discarded. The end of the drainage tube was placed in a collecting tube positioned in ice, and six, one hour collections were made. The level of the end of the drainage tube was maintained at $15 \mathrm{~cm}$ below the level of the common bile duct.

\section{CHEMICAL METHODS}

Bile salts were measured enzymatically using $3-\mathrm{OH}$ steroid dehydrogenase, ${ }^{14}$ phospholipid by the method of Bartlett, ${ }^{15}$ and cholesterol by GLC. ${ }^{16}$ Bilirubin was determined by the diazo method. ${ }^{17}$

Biliary proteins were quantitated by a fluorometric technique ${ }^{18}$ as previously described by Gallinger $e t$ al. ${ }^{19}$ This method has been shown to be accurate as validated by quantitation of biliary proteins by amino acid analysis. ${ }^{19}$ Slab sodium dodecyl sulphate poly-
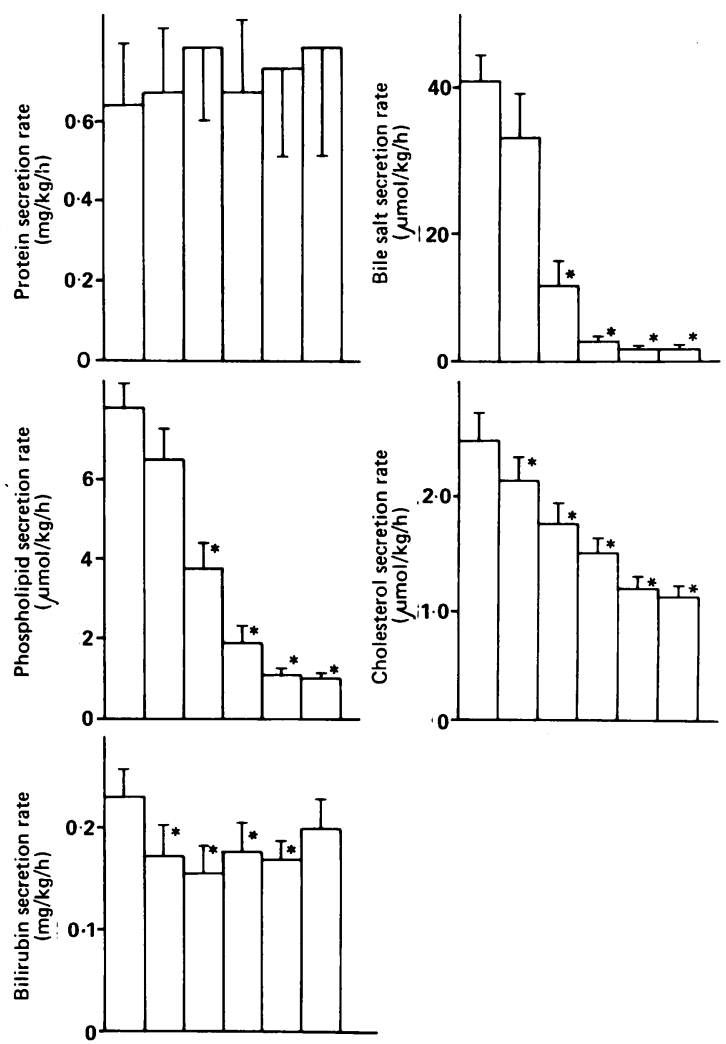

Fig. 2 Mean hourly secretion rates of biliary protein and lipids of hepatic bile collected from eight individual patients over a six hour period. Each bar represents results from bile collected over 60 minute intervals. *Significantly different from results of bile collected during first hour.

acrylamide gel electrophoresis was performed using a gradient of $5-20 \%$ with a $3 \%$ stacking gel. ${ }^{20}$ After separation by electrophoresis, proteins were stained with silver nitrate (Bio Rad silver stain kit, Richmond California). ${ }^{21}$

\section{STATISTICAL ANALYSIS}

Results were compared using the Student's paired $t$ test. As multiple testing was done the acceptable $p$ value was lowered appropriately (acceptable level of $\mathrm{p}=0.05 /$ number of comparisons by $t$ test). This placed the level of $p$ for significance at $p<0 \cdot 01$.

\section{Results}

Bile flows and concentrations of biliary lipids and proteins are given in Figure 1 . Secretion rates are presented in Figure 2. Bile flow decreased progressively in the first three hours after interruption of the enterohepatic circulation, as expected. Concen- 
trations of solutes followed one of three patterns. Bile salt and phospholipid concentrations fell. Cholesterol concentration was unchanged. Protein and bilirubin concentrations increased but the increase in protein concentration did not quite reach significance $(p=0 \cdot 07)$.

Mean protein secretion rates did not change over the six hour study period. Bilirubin secretion rate decreased slightly but significantly in the second hour, and remained steady thereafter. Secretion rates for bile salts, phospholipid and cholesterol all decreased significantly and in a stepwise manner in the first few hours. There was a close similarity in the pattern of secretion rates for bile salts and phospholipid and cholesterol, but the reductions in phospholipid secretion were less than those in bile salt secretion, and cholesterol secretion rates were least affected. The bile salt pool size calculated by the washout method ${ }^{22} 23$ was $6.47 \mathrm{mmol} \pm 0.99$ (SEM).

Examination of the protein secretion rates in individual patients (Fig. 3) reveals that five of eight

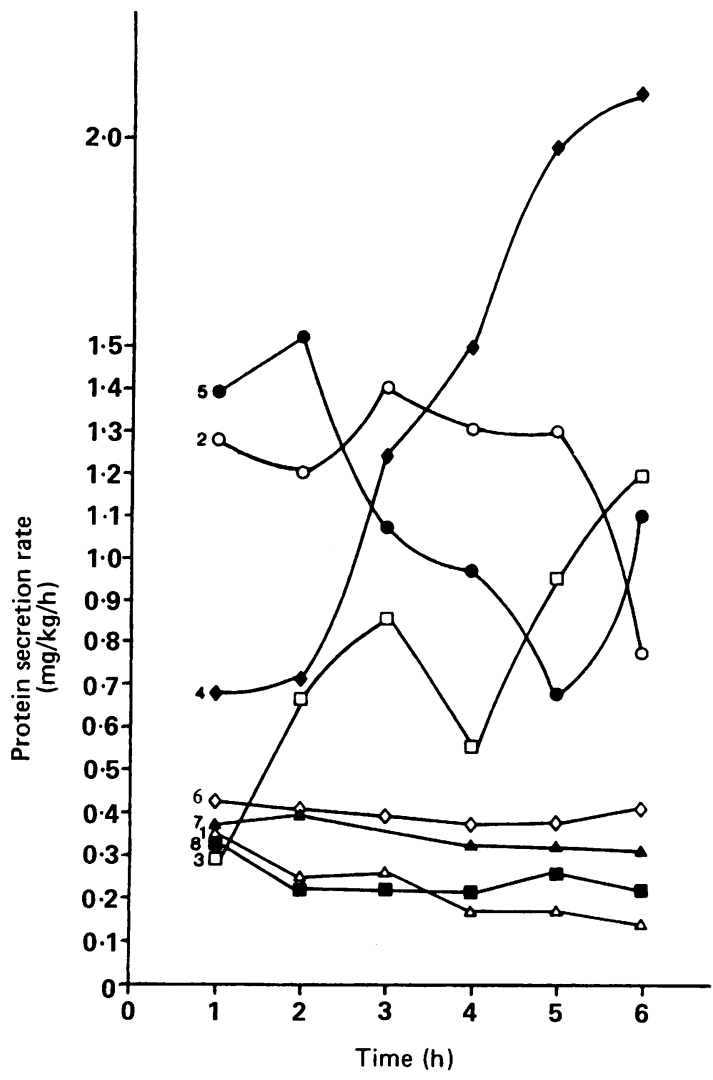

Fig. 3 Hourly protein secretion rates into hepatic bile collected in eight individual patients over a six hour period.

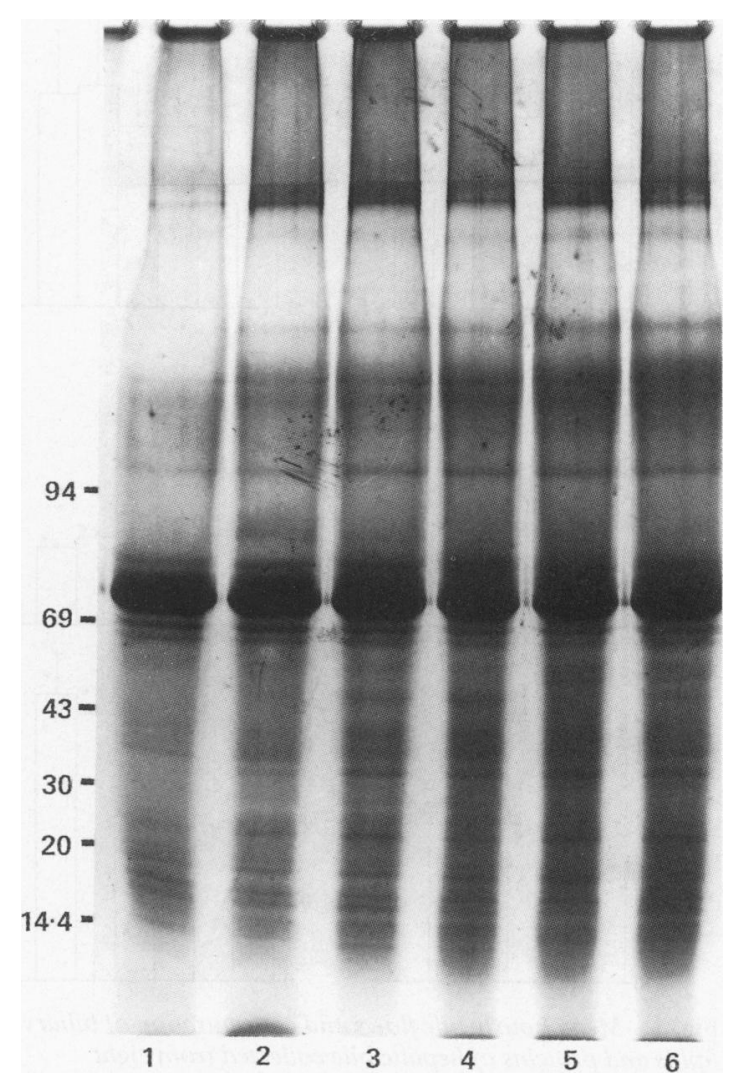

Fig. 4 SDS-polyacrylamide gel electrophoresis (5-20\% gradient) of biliary proteins. Hepatic bile was collected over 60 minute intervals for six hours. Proteins were precipitated in $7 \%$ trichloroacetic acid followed by an ether-ethanol (1:1) wash. A constant mass of protein (50 ug) as determined by fluorometric assay was applied to each lane. The gel was stained for protein with Bio Rad's silver staining kit. The number beneath each lane indicates the hourly interval over which the bile sample was collected. Migration of molecular weight markers are indicated $(k D a)$.

patients (patients 1, 2, 6, 7, and 8) had fairly steady secretion rates. Large increases in protein secretion were recorded in patients 3 and 4 and protein secretion decreased in the other patient. The range of secretion rates was large.

SDS-PAGE electrophoresis of samples from one patient are shown in Figure 4. There were no obvious changes in the bands over the six hour period. Results shown are from a patient who had a constant protein secretion rate (patient 8 ). SDS-PAGE of proteins from patients with increasing or decreasing protein secretion rates also showed no obvious changes in protein bands. 


\section{Discussion}

Bile total protein secretion rate was not related to the bile salt secretion rate in this study. The range of bile salt secretion rates obtained was large so that the failure to detect a relationship was not the result of examination of protein secretion rates over a narrow range of bile salt secretion rates. In order to obtain a high bile salt secretion rate in the first hour, the study was started 30 minutes after eating at a time when the bile salt pool would be cycling rapidly. The initial secretion rate of $40 \mu \mathrm{mol} / \mathrm{kg} / \mathrm{h}$ is at the upper range of bile salt secretion rates previously reported in man. ${ }^{24-27}$ Northfield and Hofmann found that the highest bile salt secretion rates were observed in the first hour after a meal. ${ }^{24}$ In seven control subjects the rate was $35.0 \mu \mathrm{mol} / \mathrm{kg} / \mathrm{h}$ and in seven patients with stones $37 \cdot 0 \mu \mathrm{mol} / \mathrm{kg} / \mathrm{h}$. This is very similar to our own results in the first hour (about $40 \mu \mathrm{mol} / \mathrm{kg} / \mathrm{h}$ ). The mean daily output in their study was about $60 \%$ of these levels. The highest bile salt secretion rates recorded by Shaffer and Small were about $30 \mu \mathrm{mol} /$ $\mathrm{kg} / \mathrm{h} .{ }^{26}$ On the other hand, low bile salt secretion rates (less than $2 \mu \mathrm{mol} / \mathrm{kg} / \mathrm{h}$ ) were obtained as expected in the fifth and sixth hours of our study due to the washout design of the study. We therefore conclude that over the physiological range of bile salt secretion rates, total biliary protein secretion rates are not related to bile salt secretion rates. Furthermore, no evidence was found to suggest that individual biliary proteins are substantially influenced by the bile salt secretion rate as the protein pattern evaluated by SDS-PAGE was similar throughout the study. This does not exclude the possibility that proteins present in very low concentrations such as membrane enzymes in bile are influenced by bile salt secretion rates.

This study is in agreement with that of Kakis and Yousef who used the washout method in rats. ${ }^{13}$ Total protein secretion rates remained constant over 48 hours despite large variations in the bile salt secretion rates. ${ }^{13}$ Total protein secretion rates were increased by infusion of bile salts in one study ${ }^{12}$ but the infusion rates used were high and associated in many cases with bile flow rates which fell during the course of the study, suggesting that liver cell injury may have occurred. In two other studies intravenous bile salt infusions produced raised biliary secretion of alkaline phosphatase, 5' nucleotidase or phosphodiesterase. ${ }^{910}$ The increases in these proteins did not result in a detectable increase in total biliary protein secretion rates. We did not measure these enzymes and it is unlikely that subtle changes in their concentration would be detectable by SDS-PAGE.

This study was carried out in patients with gall stones and the conclusions might not apply to normal individuals. This is an unlikely possibility as we have shown that protein concentrations in hepatic bile of patients with a variety of gall bladder problems other than gall stones are similar to those of patients with pigment or cholesterol gall stones. ${ }^{19}$ Furthermore, the patients in this study were able to rapidly restore the bile salt pool size to a normal level after the depletion associated with surgery and the maximal bile salt secretion rates were similar to that previously reported in controls. ${ }^{2427}$ It would be of interest to study normal subjects but duodenal sampling could not be used because of mixing with protein of intestinal origin, and placement of t-tube is very uncommon in patients without stones. Therefore, it is unlikely that such a study can be conducted.

A number of investigators have noted that the bileto-plasma ratio of proteins is inversely proportional to their molecular weights. It has been suggested that paracellular transport with sieving of protein may be responsible for this. ${ }^{4}$ Under these circumstances, however, one would predict that changes in bile flow would affect protein secretion substantially. This was not observed in the present study even though bile flow rates fell to less than one half of initial values. Perhaps the relative retardation of larger molecular weight protein is caused by another mechanism. It is possible for instance that larger molecular weight proteins could be hindered from approaching the plasma membrane of the hepatocyte where they are internalised in the process of fluid phase endocytosis.

It has been previously reported that bilirubin secretion rates are steady throughout the day. ${ }^{28}$ It appears, however, that at the highest bile salt secretion rates, such as those induced at the start of this study, bilirubin secretion may be augmented. It may be that this would only be seen in the immediate postprandial period when a high bile salt secretion rate follows a low bile salt secretion rate. Perhaps there is some facilitation of bilirubin transport under these circumstances or a washout of 'stored' hepatic bilirubin. ${ }^{29}$ Bile salt micelles are known to increase bilirubin solubility in bile. ${ }^{30}$

In summary, bile salts do not affect total protein secretion rates or secretion rates of proteins detectable by SDS-PAGE. The molecular size selection favouring entry of low molecular weight protein does not seem to be the result of convective sieving.

This study was supported by the Medical Research Council of Canada (MA4491) and the Physicians' Services Incorporated Foundation. Dr Harvey is a Career Scientist for the Ontario Ministry of Health, Health Personnel Development Program. This work was presented in part at the American Association for the Study of Liver Disease, Digestive Disease Week, Chicago, Illinois, May 1987. (Gastroenterology 1987; 92: 1738.) 


\section{References}

1 Dive $\mathrm{CH}$, Heremans JF. Nature and origin of the proteins of bile. I. A comparative analysis of serum and bile proteins in man. Eur J Clin Invest 1974; 4: 235-9.

2 Reuben A. Biliary proteins. Hepatology 1984; 4 [suppl]: 46-50.

3 LaRusso NF. Proteins in bile: how they get there and what they do. Am J Physiol 1984; 247: 199-205.

4 Mullock BM, Shaw LJ, Fitzharris B, et al. Sources of proteins in human bile. Gut $1985 ; 26$ : 500-9.

5 Kloppel TM, Brown WR, Reichen J. Mechanisms of secretion of proteins in bile: Studies in the perfused rat liver. Hepatology 1986; 6: 587-94.

6 Renston RH, Jones AL, Christiansen WD, et al. Evidence for a vesicular transport mechanism in hepatocytes for biliary secretion of immunoglobulin A. Science 1980; 208: 1276-8.

7 Mullock BM, Hinton RH, Dobrota M, et al. Endocytic vesicles in liver carry polymeric IgA from serum to bile. Biochim Biophys Acta 1979; 587: 381-91.

8 Mullock BM, Dobrota M, Hinton RH. Sources of the proteins of rat bile. Biochim Biophys Acta 1978; 543: 497-507.

9 Hatoff DE, Hardison WGM. Bile acid-dependent secretion of alkaline phosphatase in rat bile. Hepatology 1982; 2: 433-9.

10 Barnwell SG, Godfrey PP, Lowe PJ, et al. Biliary protein output by isolated perfused rat livers. Effects of bile salts. Biochem J 1983; 210: 549-59.

11 Hirata $\mathrm{E}$, Inoue $\mathrm{M}$, Morino $\mathrm{Y}$. Mechanism of biliary secretion of membranous enzymes: Bile acids are important factors for biliary occurrence of $\gamma$-glutamyl transferase and other hydrolases. J Biochem 1984; 96: 289-97.

12 Kitani K, Ohta M, Kanai S. Tauroursodeoxycholate prevents biliary protein excretion induced by other bile salts in the rat. Am J Physiol 1985; 248: 407-17.

13 Kakis G. Yousef IM. Protein composition of rat bile. Can J Biochem 1978; 56: 287-90.

14 Talalay P. Enzymatic analysis of steroid hormones. Methods Biochem Anal 1960; 8: 119-43.

15 Bartlett GR. Phosphorous assay in column chromatography. J Biol Chem 1959; 234: 466-8.

16 Morin RJ, Elms NJ. Rapid microanalysis of cholesterol in bile and serum by gas chromatography. Ann Clin Lab Sci 1975; 5: 52-6.

17 Heirwegh KPM, Fevery J, Meuwissen JATP, et al. Recent advances in the separation and analysis of diazo- positive bile pigments. Methods Biochem Anal 1974; 22: 205-50.

18 Castell JV. Cervesa M. Marco R. A convenient micromethod for the assay of primary amines and proteins with fluorescamine. A re-examination of the conditions of reaction. Anal Chem 1979; 99: 379-91.

19 Gallinger S, Harvey PRC, Petrunka CN, et al. Biliary proteins and the nucleation defect in cholesterol cholelithiasis. Gastroenterology 1987; 92: 867-75.

20 Hames BD. An introduction to polyacrylamide gel electrophoresis. In: Hames BD, Rickwood D, eds. Gel electrophoresis of proteins. A practical approach. Oxford: IRL Press, 1981: 1-91.

21 Merril CR, Goldman D, Sedman SA, et al. Ultrasensitive stain for proteins in polyacrylamide gels shows regional variation in cerebrospinal fluid proteins. Science 1981; 211: 1437-8.

22 Dowling RH, Mack E, Small DM. Effects of controlled interruption of the enterohepatic circulation of bile salts by biliary diversion and by ileal resection of bile salt secretion, synthesis and pool size in the rhesus monkey. J Clin Invest 1970; 49: 232-42.

23 Eriksson S. Biliary excretion of bile acids and cholesterol in bile fistula rats. Bile acids and steroids. Proc Soc Exp Biol Med 1957; 94: 578-82.

24 Hofmann AF, Northfield TC. Biliary lipid output during three meals and an overnight fast. Gut 1975; 16: 1-17.

25 Grundy SM, Duane WC, Adler RD, et al. Biliary lipid output in young women with cholesterol gallstones. Metabolism 1974; 23: 67-73.

26 Shaffer EA, Small DM. Biliary lipid secretion in cholesterol gallstone disease. J Clin Invest 1977; 59: 82840 .

27 Reuben A, Maton PN, Murphy GM, et al. Bile lipid secretion in obese and non obese individuals with and without gallstones. Clin Sci 1985; 69: 71-9.

28 Mok HYI, Von Bergmann K. Grundy S. Kinetics of the enterohepatic circulation during fasting: biliary lipid secretion and gallbladder storage. Gastroenterology 1980; 78: 1023-33.

29 Whecler HO, Meltzer JI, Bradley SE. Biliary transport and hepatic storage of sulfobromophthalein sodium in the unanesthetized dog, in normal man, and in patients with hepatic disease. J Clin Invest 1960; 39: 1131-41.

30 Goresky CA, Haddad HH, Kluger WS, et al. The enhancement of maximal bilirubin excretion with taurocholate-induced increments in bile flow. Can $J$ Physiol Pharmacol 1974; 52: 389-403. 